\title{
Evaluation of the Mutagenicity Potential of Trace-Rutinosidase Variety of Tartary Buckwheat (Fagopyrum tataricum Gaertn.) Using the Ames Test
}

\author{
Tatsuro Suzuki ${ }^{*}$, Toshikazu Morishita ${ }^{2}$, Shigenobu Takigawa ${ }^{2}$, Takahiro Noda ${ }^{2}$, \\ Koji Ishiguro² \\ ${ }^{1}$ NARO Kyushu Okinawa Agricultural Research Center, Suya, Japan \\ ${ }^{2}$ NARO Hokkaido Agricultural Research Center, Shinsei, Japan \\ Email: *tsuzu@affrc.go.jp
}

Received 3 March 2016; accepted 22 May 2016; published 25 May 2016

Copyright (C) 2016 by authors and Scientific Research Publishing Inc.

This work is licensed under the Creative Commons Attribution-NonCommercial International License (CC

BY-NC).

http://creativecommons.org/licenses/by-nc/4.0/

(c) (i) (9) Open Access

\section{Abstract}

To ensure the safety of "Manten-Kirari", a non-bitter and trace-rutinosidase variety of Tartary buckwheat, we evaluated its mutagenic activity in a bacterial reverse mutagenicity assay, the Ames test. Salmonella typhimurium TA100, TA1535, TA98, TA153, and Escherichia coli WP2 uvrA were employed as test bacteria. The flour of "Manten-Kirari" was dissolved at $12-50,000 \mu \mathrm{g} / \mathrm{mL}$ in DMSO and investigated. The number of revertants did not differ compared to the negative control for all concentrations tested, whereas that in the positive control, the number of revertants was increased with or without metabolic activation for each bacterial strain tested. These results suggested that the flour of the Tartary buckwheat "Manten-Kirari" was not genotoxic.

\section{Keywords}

Tartary Buckwheat, Rutin, Rutinosidase, Quercetin, Mutagenicity

\section{Introduction}

Rutin is a flavonoid and is widely distributed throughout the plant kingdom [1]-[4]. Rutin is reported to have various effects such as strengthening the blood capillaries [5] [6], as an antioxidant [7]-[9] and to have alpha-

"Corresponding author.

How to cite this paper: Suzuki, T., Morishita, T., Takigawa, S., Noda, T. and Ishiguro, K. (2016) Evaluation of the Mutagenicity Potential of Trace-Rutinosidase Variety of Tartary Buckwheat (Fagopyrum tataricum Gaertn.) Using the Ames Test. Journal of Agricultural Chemistry and Environment, 5, 100-105. http://dx.doi.org/10.4236/jacen.2016.52011 
glucosidase inhibitory activities [10]. In addition, the clinical effects of rutin in a double-blind crossover study are investigated and reductions in serum myeloperoxidase and cholesterol levels [11], mucosal symptoms, headache, and tiredness are observed [12]. For these reasons, attention has been focused on buckwheat as a rutin-rich material for food products [13] [14].

Buckwheat is the only known cereal to contain rutin in its seeds. Among cultivated buckwheat species, Tartary buckwheat (Fagopyrum tataricum Gaertn.) contains approximately 100-fold greater rutin in the seeds than common buckwheat (Fagopyrum esculentum Gaertn.). However, Tartary buckwheat seeds also contain extremely high rutinosidase activity [15]-[17] (Figure 1). This activity is sufficient to hydrolyze the rutin present in buckwheat flour (approximately 1\% - 2\% [w/w]) within a few minutes of the addition of water [15]-[17]. However, the flour of Tartary buckwheat, also known as "bitter buckwheat", is characterized by strong bitterness, thereby limiting its use in food products.

Recently, our research group develops a Tartary buckwheat variety named "Manten-Kirari” [18] [19]. The variety is developed by crossing between trace-rutinosidase line and "Hokkai T8", which is the reading Tartary buckwheat variety in Japan. "Manten-Kirari" flour exhibits rutinosidase activity about two or three orders of magnitude less than that of the common variety of Tartary buckwheat. Therefore, the majority of the rutin in "Manten-Kirari" is not hydrolyzed. As a result, the rutin concentration in foods containing "Manten-Kirari", such as noodle or pound cake, is much higher than doughs made with other varieties, in which almost all the rutin content is hydrolyzed [20]. In addition, the flour and food products lack the characteristic bitterness of other varieties. Therefore, "Manten-Kirari" is a promising ingredient for rutin-rich food products.

Currently, very limited information regarding the safety of Tartary buckwheat or rutin is available. Wilson et al. [21] report that intravenous and intraperitoneal injections of 30 to $50 \mathrm{mg} / \mathrm{kg}$ in rats and guinea pigs, and intravenous injections of 100 to $200 \mathrm{mg} / \mathrm{kg}$ in rabbits, show no deleterious effects. Currently, rutin, such as found in "Manten-Kirari", is not widely consumed in large amounts. Therefore, to ensure the safety of "Manten-Kirari", it is necessary to evaluate its mutagenic activity. In this context, we investigate the mutagenic activity of "Manten-Kirari” flour in a bacterial reverse mutagenicity assay (Ames test).

\section{Materials and Methods}

\subsection{Flour Preparation}

Seeds of the Tartary buckwheat variety "Manten-Kirari” (trace rutinosidase variety) were milled using a test mill (Quadrumat ${ }^{\circledR}$ Junior, Brabender ${ }^{\circledR}$ GmbH \& Co., Duisburg, Germany) at the flour milling percentage of 63\%. The flour was stored at $-20^{\circ} \mathrm{C}$ until used for experiments.

\subsection{Rutin Hydrolysis of "Manten-Kirari" Flour in DMSO}

Tartary buckwheat flour (100 mg) and $1.0 \mathrm{~mL}$ of DMSO were suspended and incubated at $37^{\circ} \mathrm{C}$ for 3 hours. Next, to extract rutin and quercetin from the DMSO-suspended flour, $7.2 \mathrm{~mL}$ of methanol and $1.8 \mathrm{~mL} 0.1 \%$ phosphoric acid were added to the mixture and stored at $37^{\circ} \mathrm{C}$ for 16 hours. After extraction, the sample was centrifuged at $5000 \mathrm{~g}, 10 \mathrm{~min}$ at $20^{\circ} \mathrm{C}$, the resultant supernatant was analyzed using HPLC [17], rutin and quercetin concentrations were determined. The extracts were filtered through a $0.45 \mathrm{~mm}$ filter and applied to HPLC. HPLC was performed on an CAPCELL PAK C18 column (SHISEIDO, Japan) at a flow rate of $1.5 \mathrm{ml} / \mathrm{min}$. Elution gradient program was 0 - 20 min linear gradient from solvent A [methanol-water-phosphoric acid (30:69.7:0.3)] to solvent B [methanol]. A chromatograph was monitored at $360 \mathrm{~nm}$.

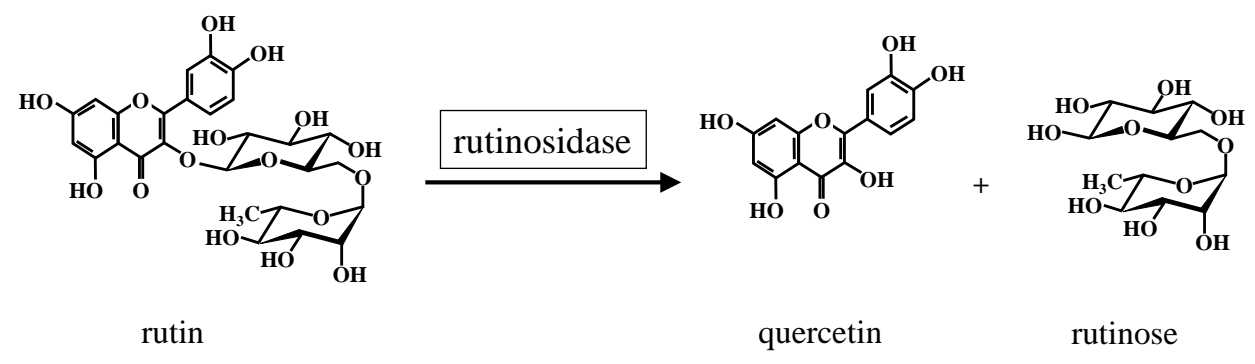

Figure 1. Rutin hydrolysis in Tartary buckwheat seeds. 


\subsection{Ames Test}

Salmonella typhimurium TA100 [22], TA1535 [22], TA98 [23], TA1537 [24], and Escherichia coli WP2 uvrA were used for the Ames test. Phenotype confirmation, genotype and mutation type detected are shown in Table 1. A preliminary experiment was conducted to optimize the test solution. Tartary buckwheat flour did not completely dissolve in any of the following solutions tested: water, acetone, N,N-dimethylformamide, 1,4-dioxisane and 1,4-epoxybutane. Of these, DMSO resulted in the best dispersion condition; therefore, we employed DMSO as the test solution. Tartary buckwheat flour and DMSO were mixed (12 - 50,000 $\mu \mathrm{g}$ flour/mL_DMSO) and subjected to sonication for approximately 2 minutes.

The S9 microsomal fraction was used as a metabolic activation system. As a positive control, B[a]P and 2AA were used in the presence of S9, while AF-2, $\mathrm{NaN}_{3}$ and ICR-191 were used in the absence of S9. The DMSO was used as a negative control. A standard preincubation assay [25] [26] was performed. In the plate incorporation method, two replicates were conducted per dose group.

In $2 \mathrm{~mL}$ of the overlay agar without $\mathrm{S} 9,0.1 \mathrm{~mL}$ of bacterial culture $\left(2.3-5.7 \times 10^{9}\right.$ bacteria), $0.1 \mathrm{~mL}$ of sample solution and $0.5 \mathrm{~mL}$ of $100 \mathrm{mM}$ sodium phosphate buffer ( $\mathrm{pH}$ 7.4) were added and mixed. Bacterial concentration was calculated using optical density. In the S9 added overlay agar, $0.5 \mathrm{~mL}$ of S9 mix was substituted for $0.5 \mathrm{~mL}$ of the sodium phosphate buffer, and the remainder of the protocol was as for the culture medium without S9 mix. Next, the molten overlay agar was added to the minimum salts agar containing $0.6 \%(\mathrm{w} / \mathrm{v})$ agar and $0.5 \%$ $(\mathrm{w} / \mathrm{v}) \mathrm{NaCl}$. After allowing the medium to harden, the plates were incubated at $37^{\circ} \mathrm{C}$ for $48 \mathrm{~h}$ and the number of revertants was recorded. These experiments were performed at BML, Inc. (BML General Laboratory, Kawagoe, Saitama, Japan) under contract from the New Drug Research Center, Inc. (Eniwa, Hokkaido, Japan).

\section{Results and Discussion}

\subsection{Rutin Hydrolysis of "Manten-Kirari" Flour in DMSO}

Although the rutinosidase activity in "Manten-Kirari" is two or three orders magnitude less than that of the common variety, some rutinosidase activity remains. Therefore, we investigated the hydrolysis of rutin by trace amounts of rutinosidase in "Manten-Kirari" flour in DMSO. Rutin concentration of DMSO-suspended flour were almost same compared with intact flour (Figure 2). In addition, aglycone of rutin quercetin, which is the product of rutinosidase activity, was not increased in DMSO-suspended flour (Figure 2). This indicates that the rutin in "Manten-Kirari” was not hydrolyzed in DMSO. Therefore, the extract contained rutin as the major polyphenolic flavonoid.

\subsection{Ames Test}

To date, there have been few reports dealing with the mutagenic activity of rutin or Tartary buckwheat. Therefore, prior to start detailed examination, we first investigated a range of Tartary buckwheat concentrations, 12 to $50,000 \mu \mathrm{g} / \mathrm{mL}$, as shown in Table 2. The positive controls showed an increase in the number of revertants both with and without S9 compared to the negative control. Also, the S9 mix or sample solution was confirmed as sterile. In the tested samples, colony numbers in "Manten-Kirari" flour did not differ from the negative control at all concentrations with or without metabolic activation for all bacteria tested. Notably, we observed precipitation with Tartary buckwheat concentrations $>3130 \mu \mathrm{g} / \mathrm{mL}$. In response, we used the concentration range $200-3130 \mu \mathrm{g} / \mathrm{mL}$ for a detailed examination, and the results are shown in Table 3. The Ames test showed no

Table 1. DNA sequence specificity of microbial test strains.

\begin{tabular}{ccccc}
\hline Allele & Strains & DNA target & Revertion event & Reference \\
\hline hisG46 & TA100 & -G-G-G- & Base-pair substitution & [22] \\
hisG46 & TA1535 & -G-G-G- & Base-pair substitution & {$[22]$} \\
trpE95 & wp2 uraA & A:T & Base-pair substitution & \\
hisD3052 & TA98 & -C-G-C-G-C-G-C-G- & Frameshift & [23] \\
HisC3076 & TA1537 & -C-C-C-C-C-C-(+1 cytosine at run of C’s) & Frameshift & {$[24]$} \\
\hline
\end{tabular}




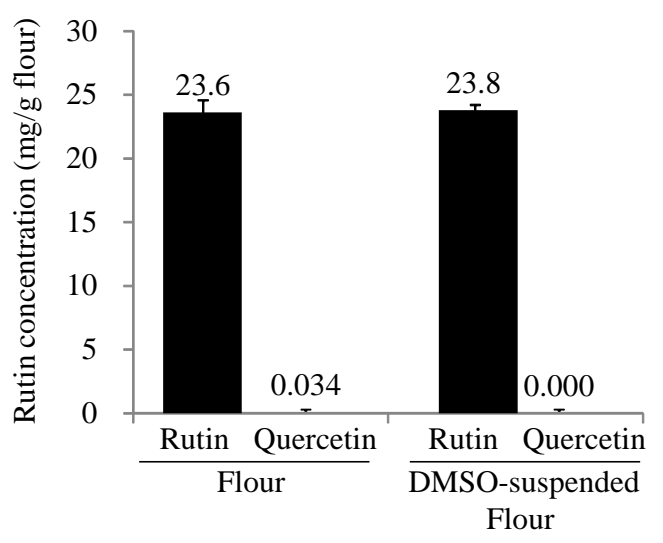

Figure 2. Rutin residual ratio in DMSO-suspended flour. There is no significant difference between flour and DMSO-suspended flour in rutin concent.

Table 2. Consideration of dose level for Tartary buckwheat flour on microbials tested with or without S9.

\begin{tabular}{cccccccccccc}
\hline concentration $(\mu \mathrm{g} / \mathrm{ml})$ & \multicolumn{2}{c}{ TA100 } & \multicolumn{2}{c}{ TA1535 } & \multicolumn{2}{c}{ wp2 uraA } & \multicolumn{2}{c}{ TA98 } & \multicolumn{2}{c}{ TA1537 } \\
& - S9 & + S9 & - S9 & + S9 & - S9 & + S9 & - S9 & + S9 & - S9 & + S9 \\
\hline Negative controles 0 & 147 & 163 & 14 & 10 & 33 & 35 & 19 & 30 & 17 & 23 \\
12 & 170 & 149 & 10 & 13 & 33 & 31 & 18 & 29 & 19 & 21 \\
49 & 159 & 147 & 13 & 10 & 33 & 34 & 21 & 31 & 18 & 24 \\
200 & 146 & 162 & 15 & 10 & 29 & 30 & 16 & 33 & 16 & 23 \\
780 & 156 & 160 & 14 & 11 & 32 & 30 & 18 & 29 & 16 & 24 \\
3130 & 161 & 164 & 11 & 10 & 32 & 31 & 16 & 27 & 16 & 19 \\
12,500 & 159 & 175 & 11 & 11 & 32 & 31 & 19 & 29 & 15 & 19 \\
50,000 & 148 & 169 & 10 & 11 & 32 & 28 & 16 & 28 & 14 & 19 \\
Positive controls & 605 & 949 & 130 & 332 & 143 & 315 & 604 & 225 & 1820 & 95 \\
Substance & AF-2 & B[a]P & NaN & 2 AA & AF-2 & 2 AA & AF-2 & B[a]P & ICR-191 & B[a]P \\
\hline
\end{tabular}

Data are means of two independent experiments.

Table 3. Effect of different dose of Tartary buckwheat flour on microbials tested with or without S9.

\begin{tabular}{|c|c|c|c|c|c|c|c|c|c|c|}
\hline \multirow[t]{2}{*}{ Concentration $(\mu \mathrm{g} / \mathrm{ml})$} & \multicolumn{2}{|c|}{ TA100 } & \multicolumn{2}{|c|}{ TA1535 } & \multicolumn{2}{|c|}{ wp2 uraA } & \multicolumn{2}{|c|}{ TA98 } & \multicolumn{2}{|c|}{ TA1537 } \\
\hline & $-\mathrm{S9}$ & +S9 & - S9 & +S9 & - S9 & +S9 & -S9 & +S9 & $-\mathrm{S9}$ & +S9 \\
\hline Negative controles 0 & 152 & 162 & 15 & 13 & 33 & 40 & 19 & 29 & 16 & 19 \\
\hline 200 & 153 & 168 & 14 & 17 & 31 & 42 & 21 & 24 & 14 & 23 \\
\hline 390 & 166 & 156 & 12 & 14 & 30 & 32 & 18 & 30 & 16 & 25 \\
\hline 780 & 162 & 169 & 13 & 14 & 34 & 32 & 17 & 22 & 16 & 19 \\
\hline 1560 & 166 & 157 & 15 & 16 & 36 & 31 & 20 & 30 & 15 & 21 \\
\hline 3130 & 169 & 163 & 16 & 15 & 27 & 35 & 23 & 32 & 15 & 19 \\
\hline Positive controls & 523 & 947 & 422 & 335 & 158 & 334 & 574 & 226 & 1710 & 85 \\
\hline Substance & AF-2 & $\mathrm{B}[\mathrm{a}] \mathrm{P}$ & $\mathrm{NaN}_{3}$ & $2 \mathrm{AA}$ & AF-2 & $2 \mathrm{AA}$ & AF-2 & $\mathrm{B}[\mathrm{a}] \mathrm{P}$ & ICR-191 & $\mathrm{B}[\mathrm{a}] \mathrm{P}$ \\
\hline
\end{tabular}

Data are means of two independent experiments. 
increase in the number of revertants for each bacterial strain tested with or without S9. In this paper, all experiments were performed in duplicate; therefore, statistical analysis could not be applied. However, the results of "Dose optimization of Tartary buckwheat flour for bacterial mutagenic assessment with or without S9" (Table 2) and "Effect of various doses of Tartary buckwheat flour on bacterial mutagenicity with or without S9" (Table 3) were almost identical in the number of revertants for each sample. Therefore, although statistical analysis could not be conducted, the results show high reproducibility. From these results, it is suggested that the flour of the Tartary buckwheat variety "Manten-Kirari" does not exhibit genotoxicity. In addition, dough at a dose of 5000 $\mathrm{mg}$ flour/ $\mathrm{kg}$ is non effect level at acute and subacute test using experimental animals [27]. From these results, "Manten-Kirari" flour should be safe. The concentration of rutin in "Manten-Kirari” flour is about $15 \mathrm{mg} / \mathrm{g}$ flour. Among several crops, Tartary buckwheat contains a notably high polyphenol concentration. Some papers have described the effect of polyphenols on mutagenic activity, assessed by the Ames test [28]. Therefore, we hypothesized that rutin may affect the number of revertants in the Ames test. However, in this experiment, "Manten-Kirari” flour did not affect the number of revertants in the Ames test, suggesting that rutin is not mutagenic.

"Manten-Kirari" is a promising Tartary buckwheat variety for use in rutin-rich food products; therefore, the results of our mutagenesis analysis provide important information for optimizing its use in the food industry.

\section{Conclusion}

Tartary buckwheat flour of "Manten-Kirari” would not have mutagenesis.

\section{Acknowledgements}

We thank Dr. Mukasa for his useful advice for planning of experiment. We thank to Mr. S. Nakamura, and Mr. K. Abe and Mr. T. Fukaya for their assistance in the field. We also thank Ms. K. Fujii, Ms. M. Hayashida, and Ms. T. Ando for technical assistance. This work was partly supported by a grant from the Research Project on Development of Agricultural Products and Foods with Health-promoting benefits (NARO), Japan.

\section{References}

[1] Sando, C. and Lloyd, J. (1924) The Isolation and Identification of Rutin from the Flowers of Elder (Sambucus canadensis L.). The Journal of Biological Chemistry, 58, 737-745.

[2] Couch, J., Naghski, J. and Krewson, C. (1946) Buckwheat as a Source of Rutin. Science, 103, 197-198. http://dx.doi.org/10.1126/science.103.2668.197

[3] Haley, T. and Bassin, M. (1951) The Isolation, Purification and Derivatives of Plant Pigments Related to Rutin. Journal of the American Pharmaceutical Association-Scientific Edition, 40, 111-112. http://dx.doi.org/10.1002/jps.3030400217

[4] Fabjan, N., Rode, J. and Kosir, I. (2003) Tartary Buckwheat (Fagopyrum tataricum Gaertn.) as a Source of Dietary Rutin and Quercitrin. Journal of Agricultural and Food Chemistry, 51, 6452-6455. http://dx.doi.org/10.1021/jf034543e

[5] Griffith, J.Q., Couch, J.F. and Lindauer, A. (1944) Effect of Rutin on Increased Capillary Fragility in Man. Proceedings of the Society for Experimental Biology and Medicine, 55, 228-229. http://dx.doi.org/10.3181/00379727-55-14532

[6] Shanno, R. (1946) Rutin: A New Drug for the Treatment of Increased Capillary Fragility. The American Journal of the Medical Sciences, 211, 539-543. http://dx.doi.org/10.1097/00000441-194621150-00003

[7] Jiang, P., Burczynski, F. and Campbell, C. (2007) Rutin and Flavonoid Contents in Three Buckwheat Species Fagopyrum esculentum, F. tataricum, and F. homotropicum and Their Protective Effects against Lipid Peroxidation. Food Research International, 40, 356-364. http://dx.doi.org/10.1016/j.foodres.2006.10.009

[8] Awatsuhara, R., Harada, K. and Maeda, T. (2010) Antioxidative Activity of the Buckwheat Polyphenol Rutin in Combination with Ovalbumin. Molecular Medicine Reports, 3, 121-125.

[9] Matsubara, Y., Hiroyasu, K., Yoshitomi, I., Tetsuo, M., Kozo, O., Hideo, K. and Katsumi, Y. (1985) Structure and Hypotensive Effect of Flavonoid Glycosides in Citrus unshiu Peelings. Agricultural and Biological Chemistry, 49, 909914.

[10] Li, Y.Q., Zhou, F.C. and Gao, F. (2009) Comparative Evaluation of Quercetin, Isoquercetin and Rutin as Inhibitors of Alpha-Glucosidase. Journal of Agricultural and Food Chemistry, 57, 11463-11468. http://dx.doi.org/10.1021/jf903083h

[11] Wieslander, G., Fabjan, N., Vogrincic, M., Kreft, I., Janson, C., Spetz-Nyström, U., Vombergar, B., Tagesson, C., 
Leanderson, P. and Norbäck, D. (2011) Eating Buckwheat Cookies Is Associated with the Reduction in Serum Levels of Myeloperoxidase and Cholesterol: A Double Blind Crossover Study in Day-Care Center Staffs. The Tohoku Journal of Experimental Medicine, 225, 123-130. http://dx.doi.org/10.1620/tjem.225.123

[12] Wieslander, G., Fabjan, N., Vogrincic, M., Kreft, I., Vombergar, B. and Norbäck, D. (2012) Effect of Common and Tartary Buckwheat Consumption on Mucosal Symptoms, Headache and Tiredness: A Double-Blind Crossover Intervention Study. Journal of Food, Agriculture and Environment, 10, 107-110.

[13] Kreft, I., Fabjan, N. and Yasumoto, K. (2006) Rutin Content in Buckwheat (Fagopyrum esculentum Moench) Food Materials and Products. Food Chemistry, 98, 508-512. http://dx.doi.org/10.1016/j.foodchem.2005.05.081

[14] Ikeda, K., Ikeda, S., Kreft, I. and Rufa, L. (2012) Utilization of Tartary Buckwheat. Fagopyrum, 29, 27-30.

[15] Yasuda, T., Masaki, K. and Kashiwagi, T. (1992) An Enzyme Degrading Rutin in Tartary Buckwheat Seeds. Journal of the Japanese Society for Food Science and Technology, 39, 994-1000. http://dx.doi.org/10.3136/nskkk1962.39.994

[16] Yasuda, T. and Nakagawa, H. (1994) Purification and Characterization of Rutin-Degrading Enzymes in Tartary Buckwheat Seeds. Phytochemistry, 37, 133-136. http://dx.doi.org/10.1016/0031-9422(94)85012-7

[17] Suzuki, T., Honda, Y., Funatsuki, W. and Nakatsuka, K. (2002) Purification and Characterization of Flavonol 3-Glucosidase, and Its Activity during Ripening in Tartary Buckwheat Seeds. Plant Science, 163, 417-423. http://dx.doi.org/10.1016/S0168-9452(02)00158-9

[18] Suzuki, T., Morishita, T., Mukasa, Y., Takigawa, S., Yokota, S., Ishiguro, K. and Noda, T. (2014) Discovery and Genetic Analysis of Non-Bitter Tartary Buckwheat (Fagopyrum tataricum Gaertn.) with Trace-Rutinosidase Activity. Breeding Science, 64, 339-343.

[19] Suzuki, T., Morishita, T., Mukasa, Y., Takigawa, S., Yokota, S., Ishiguro, K. and Noda, T. (2014) Breeding of "Manten-Kirari”, a Non-Bitter and Trace-Rutinosidase Variety of Tartary Buckwheat (Fagopyrum tataricum Gaertn.). Breeding Science, 64, 344-350.

[20] Suzuki, T., Morishita, T., Takigawa, S., Noda, T. and Ishiguro, K. (2015) Characterization of Rutin-Rich Bread Made with "Manten-Kirari”, a Trace-Rutinosidase Variety of Tartary Buckwheat (Fagopyrum tataricum Gaertn.). Food Science and Technology Research, 21, 733-738.

[21] Wilson, R.H., Moratarotti, T. and Doxtader, E. (1947) Toxicity Studies on Rutin. Experimental Biology and Medicine, 64, 324-327. http://dx.doi.org/10.3181/00379727-64-15781

[22] Barnes, W., Tuley, E. and Eisenstadt, E. (1982) Base-Sequence Analysis of HisC Revertants of the hiG46 Missense Mutation in Salmonella typhimurium. Environmental Mutagenesis, 4, 297 (abstr. Aa-1).

[23] Isono, K. and Yourno, J. (1974) Chemical Carcinogens as Frameshift Mutagens: Salmonella DNA Sequence Sensitive to Mutagenesis by Polycyclic Carcinogens. Proceedings of the National Academy of Sciences of the United States of America, 71, 1612-1617. http://dx.doi.org/10.1073/pnas.71.5.1612

[24] Ames, B.N., Lee, F.D. and Durston, W.E. (1973) An Improved Bacterial Test System for the Detection and Classification of Mutagens and Carcinogens. Proceedings of the National Academy of Sciences of the United States of America, 70, 782-786. http://dx.doi.org/10.1073/pnas.70.3.782

[25] Maron, D. and Ames, B.N. (1983) Revised Methods for the Salmonella Mutagenicity Test. Mutation Research/Environmental Mutagenesis and Related Subjects, 113, 173-215. http://dx.doi.org/10.1016/0165-1161(83)90010-9

[26] Yahagi, T., Degawa, W., Seino, Y., Matsushima, T., Nagao, M., Sugimura, T. and Hashimoto, Y. (1975) Mutagenicity of Carcinogenic Azo Dyes and Their Derivatives. Cancer Letters, 1, 91-96. http://dx.doi.org/10.1016/S0304-3835(75)95563-9

[27] Suzuki, T., Morishita, T., Noda, T. and Ishiguro, K. (2015) Acute and Subacute Toxicity Studies on the Rutin-Rich Tartary Buckwheat Dough in Experimental Animals. Journal of Nutritional Science and Vitaminology, 61, 175-181.

[28] Zhang, T., Kawabata, K., Kitano, R. and Ashida, H. (2013) Preventive Effects of Black Soybean Seed Coat Polyphenols against DNA Damage in Salmonella typhimurium. Food Science and Technology Research, 19, 685-690. 